\title{
KIAI'S COMMUNICATION STRATEGY IN DEVELOPING RELIGIOUS CULTURE AT THE NURUL QORNAIN ISLAMIC BOARDING SCHOOL JEMBER
}

\author{
Hariyanto ${ }^{1}$ \\ ${ }^{1}$ Ibrahimy University, Situbondo \\ *Corresponding Address: hariyantolppm@gmail.com
}

Naskah diterima: 6 Agustus 2021| Disetujui: 1 September 2021 | Diterbitkan: 2 September 2021

\begin{abstract}
Kiai's leadership strategy in developing a religious culture is an effort to implement the strategic ideas that have been designed in the development of the Islamic boarding school organization so that it is always by its main objectives. In Pondok Pesantren Kiai is the main symbol and the only one who has the prerogative in running an educational institution. However, nowadays pesantren is experiencing rapid development where pesantren not only organize religious activities but also manages various other formal educations. Of course, this has implications for the increasing number of educators and education personnel who ultimately need good and proper management. This development certainly needs to be responded with good communication patterns, in order that all pesantren residents can understand the information messages conveyed by Kiai as the highest leader in the pesantren. Therefore, in the management of the Nurul Qornain Islamic Boarding School, Kiai Yazid Karimullah has approaches to effective communication patterns with his students, so that the availability of channels has implications for receiving students for information.
\end{abstract}

Keywords: communications; kiai; religious culture.

Abstrak: Strategi kepemimpinan Kiai dalam mengembangkan budaya religius merupakan upaya mengimplementasikan gagasan strategi yang telah dirancang dalam pengembangan organisasi pondok pesantren agar sesuai dengan tujuan utamanya. Di Pondok Pesantren Kiai merupakan simbol utama dan satu-satunya yang memiliki hak prerogatif dalam menjalankan institusi pendidikan. Namun demikian, dewasa ini pesantren mengalami perkembangan pesat di mana pesantren tidak hanya menyelenggarakan kegiatan keagamaan saja, namun juga telah mengelola berbagai pendidikan formal lainnya. Hal ini berimplikasi pada jumlah tenaga pendidik dan kependidikan yang jumlahnya bertambah sehingga butuh pengelolaan yang baik dan tepat. Perkembangan tersebut perlu direspon dengan pola komunikasi yang baik, sehingga seluruh warga pesantren dapat memahami pesan-pesan informasi yang disampaikan oleh Kiai sebagai pemimpin tertinggi di pesantren. Karenanya dalam pengelolaan Pondok Pesantren Nurul Qornain Kiai Yazid Karimullah memiliki pendekatan-pendekatan pola komunikasi efektif dengan santrinya, sehingga ketersediaan channel berimplikasi pada reciever santri atas informasi.

Kata kunci: komunikasi; kiai; budaya religius

2656-9779 (C) 2020 The Author(s).

Published by Lembaga Penerbitan dan Publikasi Ilmiah Program Pascasarjana IAI Sunan Giri Ponorogo. This is an open access article under the CC BY-SA 4.0 license. DOI: 10.37680/qalamuna.v13i2.930 


\section{INTRODUCTION}

Islamic education is one form of effort to instill and develop Islamic teachings, so that various maturity is achieved, especially in faith and piety in the broad sense (Nor \& Malim, 2014; Aibak, 2003). Pesantren is an Islamic education which is also known as traditional education which can reform itself by continuing to develop a system, one of which is by adopting modern learning processes that are widely scattered, initiated and disseminated by people who inflame religious spirit in stemming the pace of modernization of capitalist globalization (Soyomukti, 2015). The spirit of globalization calls for the need for pesantren to strengthen their role, confirming the existence of pesantren in this era of disruption 4.0. Of course, by not leaving the typical models of the nobility of Islam in the archipelago, besides that, pesantren must also have the ability to respond to the times with creative, innovative and transformative approaches.

In Constitutions no. 18 of 2019 concerning Islamic Boarding Schools in Chapter 1 Article 1 (Mustofa, 2020), it is stated that Islamic Boarding Schools are community-based institutions established by individuals, foundations, Islamic community organizations, and/or communities that instill faith and piety to Allah SWT, instill noble character and adhere to Islamic rahmatan lil alamin teachings which are reflected in the attitude of humility, tolerance, balance, moderation and other noble values of the Indonesian nation through education, Islamic da'wah, exemplary and community empowerment within the framework of the Unitary State of the Republic of Indonesia. Pesantren education is education organized by Islamic boarding schools and located in the pesantren environment by developing a curriculum in accordance with the uniqueness of the pesantren based on the classic book or considered Islamic with the pattern of Muslim education.

Pesantren has a distinctive culture from the surrounding cultures (Mundiri, 2017). Some researchers call it an idiosyncratic sub-culture. The way of teaching is unique. The Kiai, who is usually an educator and owner of a pesantren, reads classical Arabic religious manuscripts (known as the "yellow book"). While the students listen and give notes (ngesahi, Javanese) on the book that is being read. This method is called bandongan or collective learning process. In addition, the students are also assigned to read the book, while the qualified kiai or ustadz will correct and evaluate the reading and performance of students. This method is known as sorogan or individual service (individual learning process). The teaching and learning activities take place without strict classes and curriculum tiers and are usually conducted by separating the sexes of students (Sulthon, 2006).

Culture has various definitions, for instance, Tylor defines culture as a whole complex including knowledge, belief, art, morals, science, law, customs, and other capabilities and habits acquired by humans as members of society. Selo Soemardjan defines it with all the works, tastes, and creations 
of the community. After the explanation above, Bambang Rustanto said that culture can be defined as a system in a society where there is an interaction between individuals/groups with other individuals/ groups and creates a certain pattern, which is established a collective agreement then (Rustanto, 2015).

As an educational institution, Islamic boarding schools promote a value system by accessing religious teachings by rendering the yellow book literature compiled by earlier salaf scholars as one of the hallmarks of culture. From this classical intellectual treasure, pesantren can absorb religious teachings which are then used as references for the development of value systems in daily religious and social life (Yasid, 2018).

One of the religious cultures which is deeply rooted in Islamic boarding schools is Khidmah. Among students, the term khidmah is already popular and familiar, because khidmah is believed to be a wasilah or a manner to achieve the blessing of knowledge, and therefore students always train to devote themselves so that the blessings of knowledge always flow to them. Khidmah for santri becomes a way of connecting the hearts of students and teachers (to each other) with a dedication which will replace the teacher wherever he is.

The kiai is the core factor of the pesantren. He is a central figure because the entire management of the pesantren is centered on him. He is also the main source of matters relating to leadership, knowledge, and the vision and mission of the pesantren (Mastuhu, 1997). The leadership of the kiai in the pesantren must be visionary, have a vision of where to develop the pesantren by the demands of the times. Richard Hughes and Katherine Coralleri in their book Becoming A Strategic Leader place vision as one of the five points of strategic thinking inherent in strategic leadership besides the ability to assess the organization (scanning), the ability to see things differently (reframing), to create an understanding of certain situations (making common sense) and thinking systems (Hughes \& Beatty, 2014).

The figure of Kiai has authoritative rights in operating the boarding school system performed by his subordinates later. This can be interpreted that the leadership of the kiai in Islamic boarding schools is very identical with the gestalt phenomenon, namely the whole is greater than its parts, considering that what is visible from the outside, there are still other unique characteristics that are not visible (Sulthon, 2006).

In an effort to change society, da'wah in increasing community participation in pesantren is very dependent on how the kiai communicates in building good relations in the pesantren environment, the better the kiai's communication, the more harmonious the kiai will be. When both 
have good relationships, there will be awareness senses of having pesantren, ensuring its existence in the midst of society as a pesantren institution.

Communication is the need of every individual, as well as in Islamic boarding schools because communication has a significant role in moving the organizational system. Therefore, kiai needs to have well-skilled communication. There are two reasons why a kiai as a leader in a boarding school must have effective communication skills. First, communication is the process of implementing the functions of planning, organizing, leading, and controlling management. Second, communication is an activity which spends lots of time for leaders (Stoner, 1986).

As a source of knowledge and an elder community leader, the position of the kiai in the Islamic boarding school cannot be separated from the communication he made to the santri, wherewith all his limitations, the kiai must be able to become a protector of the santri and the pesantren.

\section{METHODS}

Qualitative research and natural settings are applied, which search to present a complete picture of what will be studied (Taylor, 1985). The source of data used is a natural setting with natural phenomena. By considering field situations that are as equitable as they are, not manipulated, and without being regulated by experiments or tests (Nasution, 1992). The phenomenon to be studied is a case that requires an in-depth descriptive study with the aim of obtaining a comprehensive picture of the kiai's leadership (Yin, 2015).

The naturalistic paradigm is applied because it allows researchers to understand the behavior of teachers (kiai) and students (umana'/managers) in Islamic boarding schools to find the meaning of each phenomenon, so that they are expected to find local wisdom, tradition wisdom, moral values (emic, ethical and noetic), and theories of the researched subject.

Because qualitative research understands the underlying meaning of participant behavior, describes complex settings and interactions, explores to identify types of information, describes phenomena (Faisal, 1990). There are three general interrelated activities which determine the qualitative research process. The three activities have received different designations, including theory, analysis, ontology, epistemology, and methodology (Denzin \& Lincoln, 2011).

\section{RESULTS AND DISCUSSION}

In the decision-making process in particular and every interaction and organizational activity in general, there will be an interpersonal relationship or communication between its members. As in 
the process of making a decision, the communication process often faces failures and obstacles that come from the attitudes and behavior of different people, such as assertiveness, non-assertiveness, or can be aggressive (Mulyadi, 2018).

Three conceptual frameworks in understanding communication offered by Tubbs and Moss(Tubbs, 1983), Sereno and Bodaken (Sereno \& Bodaken, 1975), are communication as a unidirectional action (linear), communication as an interaction, and communication as a transaction. First, communication as a linear concept explains that communication is a messenger from a person or organization to another person or group of organizations that is carried out directly or through the media (Mulyana, 2016).

Richard L. Daf stated that communication is a process of exchanging information which must be understood by others with the goal of influencing and motivating behavior. The information provided refers to the words of the written message and the expression of the spoken message and possibly in other forms as nonverbal messages (Daft, 2006).

Stoner describes communication as a process that humans use in their efforts to share through the transmission of symbolic messages (Stoner, 1986). Stoner's definition has three main points, namely: first, communication involves other people, implying that communication aims to understand the way humans relate to each other. Second, communication is a similar meaning. Third, forms of communication involve symbols, gestures, sounds, letters, numbers, and words which are only used to represent or approximate the ideas they intend to communicate.

Mark E. Hanson gave an explanation in the communication process with human relations theory which later became a social systems theory known as the S-M-C-R model which means that there are at least four things that need to be considered in the communication process, namely: 1). $\mathrm{S}=$ Source, 2). $\mathrm{M}=$ Message, 3). $\mathrm{C}=$ Channel, 4). $\mathrm{R}=$ Receiver (Hanson, 1996).

In the perspective of the classical theory of scientific management, Taylor defines communication as a medium for vertical leadership control with formal channel media, so that communication is articulated as a process of conveying ideas, thoughts, and concepts from one person to another. This means that communication is like a media container as an intermediary to convey messages from one to another.

Human relations originating in the Howtorne Study provides the view that the SMCR model is more informal communication. This means communication as a process of exchanging values. Meanwhile, in the view of open systems, communication is a means of conveying messages and 
meanings to each other between organizations and their environment and also various network systems with which there are interdependencies.

In communication, certainly, it is necessary to describe a communication event that exists within the scope of the kiai and the environment around the pesantren, which can describe the situation completely. It is required because of the very large role of the kiai, both in the internal and external spheres of the pesantren. Therefore the role of the kiai in strengthening commitment as an effort to maintain the pesantren tradition is essential by using the Berlo SMCR communication model (Barlo, 1960).

In the process of developing religious culture at the Nurul Qornain Islamic Boarding School, something important to get serious attention is the pattern of how the kiai's leadership can popularize and instill these values to the whole family in the Islamic boarding school. This is undertaken to ensure that all members can understand well the messages conveyed as a strong cultural foundation. Then, this is important to understand how a Kiai as a leader can communicate his vision and be received well by his subordinates.

Mastery of effective communication is completely needed by leaders. There are many reasons to justify this, including the existence of communication as a process in implementing the functions of planning, organizing, leadership, management control, and communication as an activity that is highly wasting time for leaders. Controlling a good communication system is also useful for minimizing misunderstandings that could occur because good communication will create a conducive atmosphere, and the goals decided by a leader will be easy to achieve. Otherwise, bad communication will take up more time because it will trigger conflicts both small and large scale, thus it will interfere in achieving goals in the development of religious culture in Islamic boarding schools.

Kiai as a leader in pesantren can apply communication to perform various tasks in his responsibility. The existence of information can be transferred by various media or communication channels under the purposed goals and objectives. With the information, it will be the basis of a leader's database in the planning process: because every arranged plan needs to be communicated and socialized to other parties/partners in order to be noticed or implemented by their main tasks and functions. Furthermore, the nodes in the organization need to be advanced properly. In the advancing process, communication is required as an instrument to convey messages to others regarding the work tasks which must be achieved. Leaders perform management functions in each of their interests by using communication with others.

That is what Kiai Yazid Karimullah has succeeded in conveying his intentions and various interests, especially about developing religious culture at the Nurul Qornain Islamic Boarding School 
Jember. Then the method he applied is to use various channels which are possible to communicate effectively as an effort to develop religious cultures in boarding school.

Kiai Yazid has various agencies to communicate and convey messages to his students. As an exemplary figure, he reveals messages by using not only texts and oral messages but also symbols in the form of actions. Leadership behavior is a means of communication in developing religious culture. This is important for a kiai to understand how broad communication. Therefore what we need to be realized is that the kiai is not only a leader of the pesantren, but he is a meritorious symbol for his followers. So, not only do his words turn into role models but also his behavior becomes an image imitated by his subordinates.

The ability to communicate here is influenced by the kiai's good understanding of religious literacy so that it can be internalized in a reliable communication pattern as well. As the statement above, the development of the religious culture of the Kiai Yazid Islamic boarding school conducted the culture of cleanliness as values whose sources are taken from religious values instilled in every santri. So that students are aware that cleanliness is part of religious teachings.

The words conveyed by Kiai are able to bring peace to every santri and boarding school management. Besides having sentences full of motivational meaning and examples, he also has a very high sense of humor, so this will relate to the perception of people who would feel a sense of kinship and closeness with Kiai. Haris Kurniawan stated that he is also humorous, especially to those who are familiar with the jokes.

Kiai Yazid's communication approaches in conveying religious-cultural messages are very diverse. Some of them, as stated above, are symbolic approaches in the development of religious cultures, such as by giving direct examples to the students in the field of Islamic boarding school in environmental hygiene culture. The kiai's behavior certainly has a message revealing to students from the examples shown by him. The body expression in taking the garbage directly and then throwing it into its place is an important message to the santri so that they can understand and do the same thing that has been done by Kiai Yazid Karimullah. Leaders who set good examples will have a very positive impact on the expressions shown by subordinates.

Non-verbal communication through behavioral symbolization becomes a communication instrument that can be presented within the community. Some signs and symbols performed by the Islamic boarding school actually become tools that are widely used by kiai and his subordinates in their social interactions. Then, with non-verbal communication, the kiai wants to reveal a message to the santri and the pesantren administrator as the recipient of the message. 
The communication awareness that has been performed by Kiai Yazid was born from a good understanding of religious construction, which has implications for communication patterns emphasized through messages which have value from the perspective of religious awareness. So that it has implications for the strength of message delivery to students who consider that every action which is not following what the Kiai is doing is a form of disgraceful behavior.

The urgency of the kiai's behavior as a communication channel does not mean disengaging from other communication channels. Kiai understands very well when communication channels with action channels are utilized, when communication channels with text media are provided and when communication channels with voice are spoken.

Furthermore, in maintaining and developing religious culture, the Kiai applies letter texts. According to him, this is also often done to ensure that several things related to the message to be conveyed can be processed with better language characters and can be read by all his subordinates, in addition to using the text of the letter, the manuscript can be edited first so that there are no errors and no additions so that messages conveyed through the mail channel can be received by students and boarding school administrators. Besides the text of the letter can be archived properly, so that when it is needed again, the existing archive can be accessed and saved as a document in the Islamic boarding school.

In the communication process implemented by Kiai Yazid, one of the interesting things is that the Kiai's communication style is gradual or tiered, meaning that the messages to be revealed through the various channels described above are realized by Kiai Yazid by ensuring that the information message had been conveyed previously, discussed and noticed by the administrators of the pesantren through meetings, deliberation or discussions. From this process, Kiai understands the importance of efficient communication and well-delivered messages to avoid miscommunication which will cause fatal consequences in strengthening religious culture.

Each time kiai observes any distinction in the implementation of responsibilities in the pesantren, confirmation will be created directly to the officers and person in charge of the sector. This communication channel is certainly not only a message transmission, but also a form of attention and sense of belonging by kiai to the environment, and the education style of Kiai to subordinates. This model is certainly the Kiai's effort in communicating with the santri as an effort to develop a religious culture by integrating it based on religious values. Besides being strengthened by riyadoh as previously described, it also strengthens students with other social activities. The connectivity of the message which Kiai wished to convey is by developing a culture of cleanliness based on religious values. As a leader, he intended to explain a social message through strengthening good religious 
awareness in Islamic boarding schools. This is reinforced by the students' explanation that Kiai always explains the importance of cleanliness culture enhanced by religious values.

The importance of the Kiai's role as the main symbol affects the strength of the communication he succeeded as a charismatic figure. Then every revealed message will be well received by the communicant, especially the message conveyed using religious teachings so that it is more effective to be understood properly. Kiai uses proper grammar so that his subordinates will listen, appreciate the messages and deliver a good response to the religious-cultural messages transmitted by the kiai.

Whether the assessment of the implemented communication strength level is effective or not is related to the extent of communicant responds to the messages conveyed by the source of the channel used. With Kiai's communication style, verbal and non-verbal certainly have implications for the success of receiving and implementing subordinates on granted orders. Positive feedback means that communication is successful, while negative feedback indicates the need of evaluation in the communication model and reassures the communication channel which will be next adopted so that the process of developing religious culture is executed properly.

In the interaction of Kiai and santri, obviously many messages are revealed, especially nonverbal messages which often have to be understood with sensitivity to feelings, thoughts, and actions. Considering without a sense of taste, the nonverbal messages conveyed by Kiai will be tough to understand well by the students. Therefore, there is a need for strengthening explanation of the Kiai's non-verbal messages to less sensitive students. So that senior administrators or students can also help explain Kiai's nonverbal communication to other students.

As the statement explained earlier, the interaction between the kiai and his subordinates is built with a pattern of communication that includes formal and non-formal. Formal communication is a communication which tends officially and is implemented formally and structured through directives and or is an instructive method based on the pattern of organizational structure. The kiai can order organization units some tasks to be achieved according to the expected goals, especially in relation to the development of religious culture. This formal communication can be through formal channels within the pesantren organization and managed according to the existing structure within the pesantren. The flow of Kiai's formal communication can be determined with downward communication which implies that subordinates must communicate more with the leadership. This communication can be through written mechanisms and official meetings.

Meanwhile, non-formal communication is communication accomplished by Kiai unofficially so that directly they can handle it without paying attention to certain structural systems. In this nonformal communication, the kiai can communicate naturally without being planned. It appears clearly 


\section{Hariyanto}

when kiai sees something which is not following his view, he will immediately communicate at that place and even contact the board of pesantren and the responsible parties in case that religious culture can be re-directed. In the non-formal communication process implemented by kiai, when he saw that the location was experiencing obstacles, he immediately took action by using verbal and nonverbal communication to solve it.

Kiai Yazid's direct presence in the development of religious culture is performed through sharing of authority and management which has adopted a modern communication pattern by creating the structure a hierarchy in building communication channels between pesantren administrators and santri, so that command and coordination line of organizational communication can stably move and handle according to the task.

This top-down communication model illustrates that the kiai's sensitivity in building good communication as a form of appreciation in the process of manifesting religious culture in pesantren. With this pattern, the kiai begins the communication process with his subordinates, remembering that in the pesantren world, when subordinates initiate or open communication first, it is considered as something taboo and even impolite.

The process of top-down communication is also important as a form of leadership attention to subordinates, at least in the process of developing religious culture, aspects of shortcomings will be seen and must be improved and things which need to get serious attention. In addition, the Kiai can directly provide assistance as his special attention in providing education to subordinates about what is required to be done and resolved, and if obstacles exist, Kiai can provide comments on these problems.

The next communication implemented by Kiai Yazid is a bottom-up communication model. In this communication, what Kiai Yazid succeeded in is providing space for subordinates to take innovative and creative actions in the development of religious culture, which can be finished as a responsibility in managing organization parts in the boarding school. Subordinates can design actions very well and maturely, then the results of the innovation process are conveyed and discussed with caregivers as leaders in Islamic boarding schools.

Bottom-up communication (from bottom to top) was built by Kiai Yazid Karimullah to keep the communication of religious culture development flowing by subordinates to leaders or, in other words, communication which occurs from lower levels to higher levels. Certainly, the efforts created by Kiai have the hope of providing feedback and suggestions and submitting questions to be asked in order that the existing culture can be maintained and even some proposals can be strengthened and 
developed. In this communication, Kiai provides training to subordinates in ethics, morals and attitudes in communication skills.

In achieving the leadership of Kiai Yazid Karimullah to build communication patterns both structurally and culturally. Kiai Yazid is a pesantren leader who always sends and conveys messages with certain media, then the messages are revealed to subordinates who receive messages (receivers) then feedback occurs in the process. Kiai as the source of information is based on good religious knowledge which he strengthens with references in the yellow book literature to reinforce his idea. The information source born in religious knowledge has its own power to students, including both understanding and acceptance of the information provided. Furthermore, using wise words as motivation, values in the perspective of religious awareness, and riyadhoh-based communication emphasizes inner communication, so that it creates a connection of spiritual-based values.

In the communication process, there will be built the transmission of religious cultural values which are strengthened by religious terms to build cultural construction focused on religious culture aspects of cleanliness, religious spirits explaining cleanliness, motivations from religious values, and kalam wisdom built on religious examples.

In the communication process, Kiai Yazid certainly needs channels or media to make it easier to convey messages to his students and subordinates. Therefore, to convey the information, the communication types are verbal and non-verbal: verbal including direct communication, both formal and non-formal methods, such as through meetings, recitations, commemorations of the day. Islamic events, Maulid Nabi, Isra' Mi'raj, Nuzulul Qur'an, Islamic New Year, student guardian meeting, and alumni reunion. Non-verbal communication can be worked through the symbolic examples shown by Kiai in his daily behavior, circulars, and pamphlets such as social media and pesantren web.

Besides, Kiai's communication channel media, his sense of humor, later became the communication culture in boarding school. Kiai has an identical character to 'dhebu'. In Islamic boarding schools, dhebu has a connotation in which everything conveyed by the Kiai is important to be considered and listened to carefully (Salam, 2021).

Obviously, the communication process has implications for the formed communication. The communication pattern is built with top-down and bottom-up types which imply that the recipient of the message plays an active role in the communication process. Feedback communication which responds to both two parties each other indicates that the message is well received by the recipient of the message (Higgins, Hartley, \& Skelton, 2001). Kiai's sense of humor makes the recipient of the message more fresh, relaxed, reducing stress so that the message is internalized more quickly. In his communication, Kiai wants to teach moral ethics and communication skills. 


\section{CONCLUSION}

Communication is the key to controlling management functions, therefore communication mastery is very important in order that the information built can be well received by subordinates. Interactions can be handled smoothly so that the vision of the pesantren can be achieved as quickly as possible because of effective teamwork building.

That is what Kiai Yazid Karimullah succeeded in managing the organization in his pesantren. He applied various approaches in communication so that the messages he wanted could be well received by the students.

\section{REFERENCES}

Aibak, K. (2003). Dinamika Pendidikan Islam: Studi Kritis Tantangan dan Peran Pendidikan Islam dalam Kemajuan Ilmu Pengetahuan dan Tekhnologi. Jurnal Dinamika Penelitian Pendidikan, $5(2), 1-16$.

Barlo, D. K. (1960). The process of communication: An introduction to theory and practice. New York: Rinehart and Winston.

Daft, R. L. (2006). Management. Jakarta: Salemba Empat.

Denzin, N. K., \& Lincoln, Y. S. (2011). Qualitatif Research. Yogyakarta: Pustaka Pelajar.

Faisal, S. (1990). Penelitian Kualitatif: Dasar-dasar dan Aplikasi. Malang: YA3.

Hanson, E. M. (1996). Educational administration and organizational behavior. ERIC.

Higgins, R., Hartley, P., \& Skelton, A. (2001). Getting the message across: the problem of communicating assessment feedback. Teaching in Higher Education, 6(2), 269-274.

Hughes, R. L., \& Beatty, K. C. (2014). Becoming A Strategic Leader. Jossey-Bass A Wiley Imprint. United States of America: Jossey-Bass A Wiley Imprint.

Mastuhu, M. (1997). Kyai tanpa Pesantren: KH. Ali Yafie dalam Peta Kekuatan Sosial Islam Indonesia. Bandung: Mizan Pustaka.

Mulyadi, D. (2018). Perilaku Organisasi dan Kepemimpinan Pelayanan. Bandung: Alfabeta.

Mulyana, D. (2016). Ilmu Komunikasi. Bandung: Remaja Rosdakarya.

Mundiri, A. (2017). Organizational Culture Base On Total Quality Management In Islamic Educational Institution. ADRI International Journal Of Islamic Studies and Social Sciences, $1(1)$. 
Mustofa, I. (2020). Formulasi Pendidikan Pesantren Dalam Uu Nomor 18 Tahun 2019 Tentang Pesantren (Tinjauan Kebijakan Pendidikan). Intizam, Jurnal Manajemen Pendidikan Islam, $4(1), 20-35$.

Nasution, N. (1992). Metode Penelitian Naturalistik-Kualititif. Bandung: Tarsito.

Nor, M. R. M., \& Malim, M. (2014). Revisiting Islamic education: the case of Indonesia. Journal for Multicultural Education.

Rustanto, B. (2015). Masyarakat Multikultural di Indonesia. Bandung: Remaja Rosdakarya.

Salam, M. (2021). Building Multicultural Characters Based on Pesantren Values. Journal Education Multicultural of Islamic Society, 1(2), 1-18.

Sereno, K. K., \& Bodaken, E. M. (1975). Trans-per, understanding human communication. Boston: Houghton Mifflin.

Soyomukti, N. (2015). Teori-teori Pendidikan: Dari Tradisionalis, Neo Liberal, Marxis-Sosialis, Hingga Postmodern. Yogyakarta: Ar-Ruz Media.

Stoner, J. A. F. (1986). Management Third Edition. New Jersey: Prentice-Hall.

Sulthon, M. (2006). Manajemen pondok pesantren dalam perspektif global. Yogyakarta: LaksBang PRESSindo.

Taylor, S. J. (1985). Introduction to Qualitative Research Methods: A Phenomenological Approach to the Social Sciences. New York: John Wiley and Sons. Inc.

Tubbs, S. L. (1983). Sylvia Moss, Human Communication. New York: Random House Inc.

Yasid, A. (2018). Paradigma Baru Pesantren: Menuju Pendidikan Islam Transformatif. Yogyakarta: Ircisod.

Yin, R. K. (2015). Studi Kasus: Desain dan Metode. Jakarta: PT. Raja Grafindo Persada. 
KIAI'S COMMUNICATION STRATEGY IN DEVELOPING RELIGIOUS CULTURE AT THE ...

Hariyanto 